\title{
Mg isotope disequilibrium during fluid- fluxed crustal anatexis: A case study of migmatites from the Dabie orogen
}

\author{
YANG WANG, SHAN KE *, Yong SHENG He
}

State Key Laboratory of Geological Processes and Mineral Resources, China University of Geosciences, Beijing 100083, China.

* corresponding author: keshan@cugb.edu.cn

In order to investigate the potential of $\mathrm{Mg}$ isotopes in tracing melting processes during fluid-fluxed crustal anatexis, here we report high precision $\mathrm{Mg}$ isotopic data for migmatites from the Dabie orogen. Except for one sample that have experienced metasomatism after solidification, the melanosomes have relatively homogeneous $\delta^{26} \mathrm{Mg}(-0.29 \%$ $-0.11 \%$ ), whereas leucosomes show a significant $\delta^{26} \mathrm{Mg}$ variation $\left(-0.77 \% 0 \sim-0.23 \%\right.$ ), yielding an apparent $\Delta^{26} \mathrm{MgL}_{\mathrm{L}}$ from $-0.47 \%$ to $-0.02 \%$. Given limited fractionation between biotite and amphibole $(<0.06 \%)^{[1]}$ that are dominant $\mathrm{Mg}$ carriers of the Dabie migmatites, the observed difference between leucosomes and the corresponding melanosomes can be explained neither by equilibrium partial melting nor by incongruent melting of the gneiss protoliths. Diffusion and plagioclase accumulation also cannot be the major processes responsible for the observed isotopic fractionation, given the negligible $\mathrm{Mg}$ content of feldspar and no correlations among $\delta^{26} \mathrm{Mg}, \delta^{56} \mathrm{Fe}, \mathrm{Mg} \#$, and $\left(\mathrm{Eu} / \mathrm{Eu}{ }^{*}\right)_{\mathrm{N}}$. Instead, lower $\delta^{18} \mathrm{O}$ and higher ${ }^{87} \mathrm{Sr} /{ }^{86} \mathrm{Sr}$ (i) values of the leucosomes relative to the melanosomes provide compelling evidence for influx of an external fluid. The positive $\delta^{26} \mathrm{Mg}_{\mathrm{L}}-\delta^{18} \mathrm{O}_{\mathrm{L}}$ and negative $\delta^{26} \mathrm{Mg}_{\mathrm{L}-}{ }^{87} \mathrm{Sr} /{ }^{86} \mathrm{Sr}(\mathrm{i})_{\mathrm{L}}$ correlations indicate that the external fluid most likely has a low $\delta^{26} \mathrm{Mg}$. The variably low $\delta^{26} \mathrm{Mg}$ can be explained by change of the proportion of $\mathrm{Mg}$ in the leucosomes from the external fluid and that from protoliths, given that $\Delta^{26} \mathrm{Mg}_{\mathrm{L}-\mathrm{M}}$ increases with decreasing $\mathrm{K} / \mathrm{Rb}_{\mathrm{L} / \mathrm{M}}$. $\mathrm{A}$ lower melt $\mathrm{K} / \mathrm{Rb}$ reflects melting of more biotite relative to feldspar with an increasing degree of melting. Preservation of $\mathrm{Mg}-\mathrm{Sr}-\mathrm{O}$ isotope disequilibrium suggests a fast solidification of the leucosomes after crustal anatexis, likely by devolatilization and / or rapid cooling.

[1] Liu et al., 2010, EPSL; [2] Wang et al., 2013, CMP 